\title{
HILSEPÅBUDET I ANGEL
}

\author{
AF \\ HOLGER HJELHOLT \\ DR. PHIL,, ARKIVAR I RIGSARKIVET, KøBENHAVN \\ $*$
}

$I_{e}$

en afhandling om Christian VIII i et tysk tidsskrift var der som motto sat et par linjer af et Heidenstamsk digt: „. . . men där jag går, jag ser, att rätt och heder - min ovän ock på skölden skrivet bär"1. Selv om afhandlingen efter mit skøn ikke fuldt ud svarede til mottoet, gjorde den det dog i adskilligt, og allerede det, at en tysk ved behandling af et nationalt meget omstridt emne vælger disse linjer som motto, tør måske næsten regnes for lidt af en bedrift.

Et andet emne, overfor hvilket man fra dansk side meget kunde ønske, at tyske skribenter vilde holde sig et sådant motto for øje, er det danske styre $\mathrm{i}$ Slesvig i tiden mellem krigene ( $1850-1864)$. Dette styre blev i samtiden af den tyske agitation udskreget som et ligefremt rædselsstyre, og de tyske agitatorer gjorde alt for at piske den nationale stemning i Tyskland op imod Danmark. Hertil forekom dem tilsyneladende intet middel for lavt og intet angrebspunkt for småligt. Til visse kunde man som dansk udbryde med digteren: „Vi kun hovslag fornam af den pilsnare hest, der bar løgnen blandt folkene hen “. H. P. Hanssen fortalte mig også, da jeg i sin tid arbejdede på min bog om den danske sprogordning i Slesvig, at selv socialistføreren Bebel (f. I840) fra sin ungdom havde bevaret opfattelsen af det danske styre mellem krigene som et tyranni.

Af den tyske agitations mange angrebspunkter skal i det følgende kun et enkelt behandles, men ganske vist et, som i høj grad udnyttedes. Endog af den russiske kejser blev det foreholdt danske diplomater ${ }^{2}$. Bedømmelsen af det og af, i hvilken grad man måtte finde det karakteristisk for det danske styre, skal overlades læseren af det følgende.

1 Linjerne findes i digtet „Begynd vandring“ (i Nya dikter 1915). Den nævnte afhandling er Johs. Krumm: Christian der Achte, eine tragische Gestalt der Landesgeschichte (i Nordelbingen. Bd. 7. 1928). Han citerer linjerne på tysk: „Doch wo ich gehe, seh ich Recht und Ehre Auch auf des Feindes Schild geschrieben steht“. 2 N. Neergaard : Under Junigrundloven. I. 548. 
Den 2. juli I850 sluttedes den såkaldte „simple“ fred mellem Danmark og det tyske forbund. Den II.juli udnævnte kongen sin kabinetssekretær F. F. Tillisch til som overordentlig regeringskommissær at overtage den civile styrelse af hertugdømmet Slesvig. Den 25. juli vandtes sejren ved Isted, hvorved også Sydslesvig kom under dansk styre. Oprørshæren gik tilbage til det tyske forbundsland Holsten, medens danskerne blev stående ved Ejderen, hvor deres stilling i den følgende tid blev genstand for flere angreb. Først i 1852 førte forhandlingerne mellem Danmark og de to tyske stormagter Østrig og Preussen til, at disse skred ind og afvæbnede den slesvig-holstenske hær.

Allerede denne situation førte med sig, at de danske civile myndigheder ikke straks efter Istedslaget kunde blive enerådende $i$ hele hertugdømmet. En militær besættelse af Sydslesvig var nødvendig, og der herskede her belejringstilstand indtil marts 1852 . Så længe den slesvig-holstenske hær stod under våben i Holsten, må der utvivlsomt også i Sydslesvig have været adskillige slesvig-holstensksindede beboere, der har tænkt sig muligheden af en vending $\mathrm{i}$ krigslykken eller i diplomaternes spil. I en indberetning af marts $18_{5} \mathrm{I}$ til krigsministeriet fra generalkommandoen i hertugdømmet Slesvig ${ }^{1}$ hedder det således om forholdene i Angel, at skønt alt viste sig roligt på overfladen, var der dog anledning til en skærpet årvågenhed og „en eventuel hurtig og kraftig optræden mod befolkningen eller rettere mod den del af samme, der endnu er oprørets sag hengiven“. Det var derfor anset for hensigtsmæssigt at pålægge kommandøren for 2. forstærkningsbataillon, oberstløjtnant DU PLAT ${ }^{2}$, at søge orden og rolighed håndhævet i Angel. Om det gjordes fornødent, skulde han i de distrikter, der var under belejringstilstand, optræde med selvstændig politimyndighed. Endvidere var han bleven bemyndiget til at foretage større og mindre forandringer $\mathrm{i}$ bataillonens dislokation (fordelingen af tropperne), eftersom det fandtes tilrådeligt; det havde nemlig vist sig, at de forskellige distrikters umiddelbare belægning med militær var et middel, der virkede fordelagtigt på stemningen.

I samme måned, som denne indberetning er fra, var Tillisch fra regeringskommissær bleven udnævnt til minister for hertugdømmet Slesvig. Mellem de civile og militære myndigheder kom det til adskillige rivninger om deres kompetenceområde. Således vekslede det slesvigske ministerium og generalkommandoen $i$ slutningen af april skrivelser herom ${ }^{3}$. Kommanderende general i Slesvig var G. G. v. Krogh. Ministeriet hævdede, at det ikke var nødvendigt at

1 Krigsmin. Direktionen for armeens personel. Indk. sager, prtk. IV. ${ }^{281} /{ }_{1851}$. Denne som de følgende sager findes i rigsarkivet. ${ }^{2}$ Peter Henrik Claude du Plat, f. I809. ${ }^{3}$ Krigsmin. Direkt. f. arm. pers. Indk. sager, prtk. IV. ${ }^{363 / 1851}$. 
tilstå militærmagten i Sydslesvig en selvstændig og af de civile autoriteter uafhængig stilling. Generalkommandoen holdt derimod på, at under en belejringstilstand tilkom der militærmagten en vis diskretionær (d. v. s. udøvet efter et skøn) og selvstændig myndighed. For øvrigt var begge enige om, at forholdene endnu ikke var sådanne, at belejringstilstanden kunde hæves. Generalkommandoen betonede, at der endog var distrikter uden civil øvrighed, og hvor således den militære autoritet var absolut nødvendig.

Et afgørende vidnesbyrd om rigtigheden af sin opfattelse af det uheldige i militærmagtens selvstændige myndighed følte Tillisch, at han fik ved nogle sidst $i$ april og $i$ første halvdel af maj af militære befalingsmænd i Angel udstedte bekendtgørelser. Disse bekendtgørelser er det, som indeholder det meget omtalte hilsepåbud.

Der foreligger afskrifter af 3 sådanne bekendtgørelser, der af Tillisch indsendtes til premierministeren ${ }^{1}$. Den første er dateret Savstrup (i Nørre-Brarup sogn) 29. april. Det hedder i denne, at i oberstløjtnant du Plats („Dubpla“) navn og efter mundtlig meddelelse af en underofficer er det gjort underskriveren til pligt i sit distrikt at bekendtgøre, at enhver skal aftage hat eller hue „med agtelse“ for enhver officer og overhovedet vise fornøden agtelse for enhver militær. Den anden bekendtgørelse er udstedt af en løjtnant (F. W. I. M. v. Brackel) og dateret Rydde (i Sottrup i Angel) 7. maj. Den er delt i 3 punkter, hvoraf hilsepåbudet er det første. Man skal for enhver officer tage hatten eller huen af således, „at hovedbedækningen ordentlig føres ned efter lænden“. Det var altså. ikke nok blot at tage til hatteskyggen. De to følgende punkter indeholdt forbud mod forsamlinger i værtshuse, private huse eller $\mathrm{i}$ det fri og imod petitioner samt forbud mod sang eller larm i værtshuse eller private huse, på gader eller andre pladser. Den sidste bekendtgørelse er dateret Nørre-Brarup I4. maj og udstedt af en løjtnant v. Hoppe. Den indeholder i det væsentlige det samme som den foregående. Om aftagningen af hovedbedækningen hedder det dog kun, at den skal foregå „ordentlig“, men dette ord er understreget. Hilsepligten er foruden til officerer udstrakt til alle kongelige embedsmænd. Endvidere påbydes i denne bekendtgørelse, at hvem der endnu besidder uniformsstykker fra den oprørske armé eller andre tegn på oprøret, inden 24 timer skal levere det til den kommanderende officer $\mathrm{i}$ Nørre-Brarup. Undladelse heraf trues med streng straf.

Afskrifter af disse tre bekendtgørelser sendte Tillisch den 20. maj til København. Han stilede sin skrivelse til justitsministeren, C. E. Bardenfleth, der for

1 Premierministerens arkiv. Brevnr. $94 .{ }^{23} / 5$ 185I (journalnr. ${ }^{82} / 1851$ ). 
øvrigt var hans svoger, idet han skrev, at han ikke var vis på, at premierministeren var i byen. Det var ham imidlertid vigtigt, at hans skrivelse snarest kom til statsrådets kundskab; derfor fik Bardenfleth den med bøn om at give den til premierministeren, om denne var til stede. Tillisch knyttede til bekendtgørelserne følgende bemærkninger: „At derved er foranlediget en stor forbitrelse iblandt folket, er naturligt, og at sådanne foranstaltninger lægges mig til last, er lige så naturligt, da man ikke kan begribe, at slige bestemmelser kunne gives uden mit samtykke. Den ufordelagtige virkning, som dette har på stemningen, er indlysende og har mere end noget andet skadet vor sag". Han havde ganske vist anmodet generalkommandoen om øjeblikkelig at tage de givne befalinger tilbage, men, føjede han bittert til, han vidste ikke, hvorvidt anmodningen blev taget til følge, da de militære autoriteter kun adlød de instruktioner, som gaves af krigsministeren ${ }^{1}$, og anså sig aldeles uafhængige af ham, Tillisch. Alene af denne sag fremgik det tilstrækkeligt, hvor nødvendigt det var, at forholdet mellem den civile og militære øvrighed ordnedes sådan, som man i statsrådet under hans sidste ophold i København var bleven enig om. Tillisch skriver intet om, hvad denne ordning gik ud på, men den må jo have frembudt garantier mod kompetenceoverskridelser fra de militære myndigheder. Flere andre sådanne, bemærker Tillisch til slut i sin skrivelse, vil han forbigå, da det anførte eksempel sikkert er oplysende nok. At henvende sig til krigsministeren havde han anset for unyttigt, og derfor havde han rettet sin meddelelse til statsrådet.

Tillisch' skrivelse besvaredes allerede den 23. af premierministeren, A. W. Moltke. Denne søgte at mildne bitterheden hos Tillisch overfor krigsministeren, og han var her i det heldige tilfælde, at krigsministeren også absolut brød staven over de udstedte bekendtgørelser. Det var ham, skrev Moltke, „meget behageligt " at kunne meddele, at krigsministeriet øjeblikkelig havde truffet foranstaltning til tilbagekaldelse af de omtalte bekendtgørelser. Samtidig havde krigsministeriet taget de fornødne forholdsregler til at forebygge andre sådanne beklagelige hændelser. Allerede inden Moltke havde modtaget Tillisch' skrivelse, havde krigsministeren for øvrigt den $2 \mathrm{I}$., foranlediget ved et referat $\mathrm{i}$ de hamborgske blade, krævet nøjagtige oplysninger af generalkommandoen om sammenhængen med de pågældende bekendtgørelser. Da han så af de premierministeren fra Tillisch tilsendte afskrifter fik stadfæstelse på, at de virkelig var udstedte, havde han straks pålagt generalkommandoen ufortøvet at tilbagekalde dem. Desuden havde han befalet den højstkommanderende i Angel, oberstløjtnant du Plat afløst, fra hvem bekendtgørelserne - „der iøvrigt jo

1 Krigsminister var C. F. v. Hansen. 
vistnok er fremkaldte, men derfor på ingen måde retfærdiggjorte, ved mange forudgående drillerier fra beboerne" - var udgåede. Krigsministeren beklagede ikke mindre end Tillisch, at sådanne bekendtgørelser var udstedte, og han havde benyttet lejligheden til påny at indskærpe generalkommandoen, „at der imod beboerne skal gås tilværks med al mulig humanitet og søges undgået enhver unødvendig hårdhed eller strenghed og enhver smålig befaling, der uden nødvendighed lægger bånd på beboernes frihed".

Moltke mente, at Tillisch herved vilde føle sig fuldkommen tilfredsstillet med hensyn til denne sag. Om de beklagelige differencer, der vedblivende fandt sted mellem ministeren for Slesvig og generalkommandoen, udtalte han, at han havde anmodet krigsministeren om at indskærpe generalkommandoen, at der ikke af de militære befalingsmænd gaves bestemmelser, som lå uden for deres kompetence, og at kollisioner med de civile autoriteter af al magt søgtes undgåede. Krigsministeren havde lovet dette. Moltke håbede derfor, at det ved "gensidig imødekommen og lempen" vilde lykkes at komme gennem den formentlig endnu kun korte tid, belejringstilstanden vilde vare. Ved dens ophør vilde jo de differencer, som nu desværre engang var opståede mellem de militære og civile autoriteter, af sig selv falde bort.

Hvad Moltke i sin skrivelse til Tillisch meddelte om krigsministerens optræden, var fuldkommen korrekt. I den nævnte skrivelse af 2 I. til generalkommandoen havde krigsministeren krævet indberetning om det i de hamborgske blade givne referat, hvilket han imidlertid ikke formente at behøve at fæste lid til ${ }^{1}$. „Skulde imod formodning, “ hed det dog, „nogen officer i den grad have ladet det mangle på behørig konduite, at han har kunnet lade en sådan befaling udgå, er det ministeriets vilje, at der ingen skånsel vises ham. I modsat fald venter man at modtage så fuldstændige og nøjagtige oplysninger, at det omhandlede referat med bestemthed kan modsiges". Sluttelig henlededes opmærksomheden på vigtigheden af, at afdelingskommandoer og navnlig detachementskommandører på det omhyggeligste instrueredes om den måde og den ånd, $\mathrm{i}$ hvilken deres myndighed burde udøves. Der måtte ingen unødvendig hårdhed eller strenghed vises Slesvigs beboere, og man håbede, „at den disciplin, der under de forløbne krigsår har udmærket armeen og erhvervet den et så hæderligt navn, også fremdeles vil bevare sig under de fredelige forhold".

Krigsministeren skulde ikke komme til ret længe efter afsendelsen af denne skrivelse at svæve i den vildfarelse, at efterretningerne fra Angel var „meget tvivlsomme, om ikke åbenbart opdigtede". Allerede den følgende dag afgik en

1 Krigsmin. Direkt. f. arm. pers. Kopibog I85 I. IV. Nr. $253 .{ }^{21} / 6$. 
ny skrivelse til generalkommandoen, hvori det hed, at man nu havde fået rigtigheden af de nævnte efterretninger stadfæstet ${ }^{1}$. Dette var sket både gennem flere aviser - der nævnes dog kun een - og gennem „andre kilder“. Det ser egentlig lidt mærkeligt ud, at Tillisch' skrivelse ikke nævnes. Imidlertid havde Tillisch jo ikke villet henvende sig til krigsministeren, og måske har denne derfor ikke villet nævne noget om, hvad det var for „,andre kilder“, han havde fået stadfæstelsen fra. Krigsministeren beordrede nu alle de omhandlede befalinger ufortøvet ophævede. Medens det imidlertid i skrivelsen af 21. hed, at der ingen skånsel skulde vises ophavsmændene til befalingerne, udtaltes det nu - skyldes dette mulig irritation over Tillisch' indgriben? -, at ophævelsen skulde ske på den for vedkommende befalingsmænd mindst kompromitterende måde. Hvor sådant ikke kunde undgås, skulde generalkommandoen overveje, om ikke en dislokation måtte anses hensigtsmæssig. Endelig betonedes igen, at der skulde vises beboerne al mulig humanitet: „Så længe der ikke vises åbenbar ulydighed eller opsætsighed, må under de nuværende forhold ethvert ufornødent bånd på beboernes frihed anses utilrådeligt, og det må især frarådes ved smålige og meget detaillerede befalinger af politiretlig natur at fremkalde en opposition, der kun kan hindre forholdenes ordning, og som $i$ det partis hænder, der endnu ikke har opgivet modstanden, altid bliver et våben imod os".

Ligesom krigsministeren allerede havde sat sig i bevægelse inden Tillisch' klage kom til København, således var også generalkommandoen kommen krigsministeren i forkøbet. Den havde, inden krigsministeren udstedte sine ovennævnte skrivelser, beordret de pågældende bekendtgørelser „som alle lignende“ inddragne ${ }^{2}$. $\mathrm{Da}$ den nemlig ved skrivelse af 19 . fra det slesvigske ministerium modtog den tjenstlige anmodning at hæve bekendtgørelserne, havde den straks pareret ordre. Den 20. skrev den herom til major C. W. v. Dau, der, da du Plat var på permission i København, var den højeste officer i Angel og Svansø. Den bemærkede, at den allerede sidst $i$ april måned udtrykkelig havde meddelt du Plat, at sådanne formelige bekendtgørelser, der vilde afgive et nyt agitationsmiddel, ikke ansås for hensigtsmæssige. Det havde derfor været den i højeste grad påfaldende, at de alligevel var udstedte, og endog af underordnede befalingsmænd og af et indhold, som man måtte misbillige. Det tilkendegaves, at alle til offentlig kundgørelse bestemte anordninger, der ansås fornødne til ordens og roligheds opretholdelse i den del af Angel, der var i belejringstilstand, skulde

1 Krigsmin. Direkt. f. arm. pers. Kopibog 1851. IV. Nr. 26 r. ${ }^{22} / 5^{*}{ }^{2}$ Se om det følgende den indkomne sag nr. ${ }^{104} / 1851$ Krigsmin. Direkt. f. arm. pers. Prtk. IV. 
udstedes af den højstkommanderende officer selv. Generalkommandoen vilde desuden for at kunne våge over form og indhold af sådanne bekendtgørelser have dem indsendt til approbation, inden de udstedtes. Der skulde gøres indberetning om, hvorvidt de løjtnanter, der havde udstedt de omtalte bekendtgørelser, havde været bemyndigede af du Plat til selv at udstede dem, og ligeledes om, hvorvidt den af løjtnant Brackel udgivne endog havde været bekendtgjort $i$ dele af Flensborg amt (der ikke var under belejringstilstand). I en ny skrivelse til major v. Dau dagen efter bemærkede generalkommandoen, at de i Angel udstedte bekendtgørelser havde vakt megen opsigt. Den ønskede derfor at kende motiverne til, at så alvorlige bestemmelser var tagne, „for at kunne imødegå alle påstande om en hensynsløs anvendelse af den militære magt". Ligeledes vilde den have at vide, om de forskellige bestemmelser i deres hele udstrækning var foranledigede af den højstkommanderende selv.

Den 22. vendte du Plat tilbage fra sin permission, og den 25. besvarede han $i$ en længere indberetning generalkommandoens skrivelser af 20. og 21 . Ansvaret for de udstedte bekendtgørelser påtog han sig for så vidt, som han erklærede, at deres indhold var overensstemmende med de af ham givne befalinger, „hvorimod måden, hvorpå det er sket, ikke er befalet". Det havde dog været ham bekendt, at patrouilleførere havde haft en skreven ordre med, hvorpå sognefogden måtte attestere at have gjort sig bekendt med indholdet. Aldeles ubekendt havde det imidlertid været ham, at ordrerne var forblevne $\mathrm{i}$ fogdernes hænder, ja endog opslåede. Men indholdet var altså som sagt overensstemmende med du Plats befalinger, og han hævdede, at punkterne om, at beboerne skulde være hjemme til en bestemt tid, at ingen dans eller lystighed måtte finde sted uden tilladelse, og at ingen forsamling turde afholdes, var en ligefrem følge af belejringstilstanden. Disse bestemmelser var givne og overholdte lige fra besættelsen i juli $185^{\circ}$ overalt, hvor der var stationeret tropper, og hvor der var erklæret belejringstilstand. Noget i strid hermed synes det dog at være, når han fortsætter, at ikke desmindre var de på landet først indførte lidt efter lidt, og eftersom det viste sig nødvendigt. Som bevæggrund til, at det var befalet beboerne at være hjemme kl. 9, angav han, at præsten i Sottrup (Angel) ${ }^{1}$ var bleven fornærmet af nogle fulde folk, der sildig om aftenen gik forbi hans hus. Om tidsbestemmelsen $\mathrm{kl}$. 12 for tilladelser til dans og lystighed bemærkede han, at den skyldtes uordener ved et bal i Kappel, hvor der var givet lov til at danse indtil kl. 3. Sådan havde der i lang tid været forholdt i Kappel,

1 Prasten var J. G. L. Plenge. 
Arnæs og Slesvig, hvorfor han ikke havde kunnet antage, at generalkommandoen misbilligede disse bestemmelser.

Hvad påbudet om, at landbefolkningen skulde hilse alle officerer, angik, så var dette, skrev du Plat, foranlediget ved, at „alle“ ældre folk og en del yngre stadig hilste, hvorimod den opvoksende ungdom og ligeledes nogle ældre ikke blot ikke hilste, „men ved stillinger og miner lagde den største trods for dagen“. Han havde anset det for aldeles nødvendigt at knække denne trods, „som særdeles udmærker befolkningen i dette distrikt", og derfor havde han påbudt, at alle officerer og embedsmænd skulde hilses. Af alle bestemmelser var der vistnok ingen, skrev han, der havde vakt så megen tilfredshed hos de af regeringen ansatte gejstlige embedsmænd. Før befalingen udstedtes, havde han også talt herom med den eneste politiembedsmand, der boede i hele Angel, nemlig distriktsdeputeret Hagemann ${ }^{1}$. Denne havde fundet det meget ønskeligt at „vænne befolkningen til høflighed og respekt, som den alt i mange år havde forglemt". Du Plat foreslog generalkommandoen eventuelt at indhente Hagemanns udtalelser om de givne befalinger. Sluttelig bemærkede han, at han snarest skulde indberette, hvorvidt den af løjtnant Brackel givne befaling var bekendtgjort i dele af Flensborg amt. Han hævdede, at det var bleven indskærpet, at de indskrænkninger, der var gældende $i$ belejringsdistriktet, ikke kunde udstrækkes til Flensborg amt. Men hilsepligten har han åbenbart ikke ment var en følge af belejringstilstanden, for han nævner selv, at den fandtes blandt bestemmelser, der var udstedte i Flensborg amt.

Den 28. sendte generalkommandoen du Plats indberetning til krigsministeriet og afgav samtidig en længere betænkning om hele sagen. At generalkommandoen i denne betænkning viser nogen stærk uvilje over indholdet af de givne befalinger, kan man næppe sige. Det er mere måden, hvorpå de er udstedt, den misbilliger, og den fremhæver samtidig, hvad der taler til forsvar for befalingsmændene.

Om hilsepåbudet bemærker generalkommandoen, at den allerede $\mathrm{i}$ månedens begyndelse havde erfaret, at du Plat på flere steder i Angel havde udstedt et sådant. Generalkommandoen „kunde vel ikke ganske billige denne forholdsregel og anså den navnlig ikke for en til ordens og roligheds opretholdelse nødvendig' foranstaltning ", men den havde dog af forskellige grunde indskrænket sig til at anbefale oberstløjtnanten forsigtighed. Som disse grunde anførtes, at du Plat mundtlig havde oplyst, at hilsepåbudet var fremkaldt ved den af en del af be-

1 Den loyale godsejer M. Hagemann til Udmark (Ohrfeld) i Esgrus sogn (Angel). 
folkningen udviste hån og trods; at generalkommandoen ikke kunde tænke sig, at nogen formelig bekendtgørelse blev udstedt; at sagen ikke syntes at have vakt opsigt eller uvilje hos flertallet af beboerne, „der fandt det naturligt, at der skulde vises øvrigheden agtelse“; og endelig, at påbudet ikke kunde hæves uden at kompromittere de militære befalingsmænd. Som grund til den formening, at nogen formelig bekendtgørelse ikke vilde blive udstedt, nævnte generalkommandoen sin tidligere omtalte skrivelse fra sidst i april til du Plat.

Det var derfor, bemærkede generalkommandoen videre $\mathrm{i}$ sin betænkning, aldeles uventet, da den fra den slesvigske minister modtog afskrifterne af „nogle yderst uheldigt affattede bekendtgørelser" med anmodning om at tilbagekalde dem. Hvad man i denne anledning havde foretaget sig, fremgik af de vedlagte afskrifter af skrivelserne til major v. Dau. Du Plat havde i sin indberetning påtaget sig ansvaret for de begåede misgreb, „hvilket formentligen også påhviler ham ". Generalkommandoen fremhævede her, at der vistnok havde været al anledning for ham til at indhente dens bestemmelser, inden han traf en foranstaltning af så betænkelig beskaffenhed som den omhandlede, men han havde iværksat den på egen hånd. Han havde endvidere udstrakt den til Flensborg amt i strid med generalkommandoens ofte gentagne meddelelser om forskellen mellem militærautoriteternes myndighed $\mathrm{i}$ og udenfor de $\mathrm{i}$ belejringstilstand erklærede distrikter. Endelig havde han, skønt han var vidende om, at de underordnede befalingsmænd skriftligt opsatte de mundtligt givne ordrer for at bekendtgøre dem ved udsendte patrouiller, ingen forholdsregler taget for at forebygge misgreb fra disse befalingsmænd.

Skønt generalkommandoen mente, at løjtnanterne v. Brackel og v. Hoppe havde gjort sig skyldige i malkonduite, fandt den det dog efter det foreliggende urigtigt at drage dem til retsligt ansvar. Hvad du Plat angik, fremhævede den en omstændighed, som den fandt vigtig med hensyn til det slesvigske ministeriums beklagelser over sagen, nemlig den omstændighed, at den af dette ministerium selv ansatte eneste politiembedsmand i Angel, Hagemann, aldeles havde billiget du Plats foranstaltning. Denne fremhævelse var jo lidet venlig mod den slesvigske minister, og dette var heller næppe tilfældet med bemærkningen om, „at den sensation, som sagen vakte her $i$ et par dage, efter at det herværende ministerium så uventet havde grebet ind i samme ad tjenstlig vej, atter har lagt sig“. Både på grund heraf og ved hjælp af den forestående dislokation ventede generalkommandoen at kunne undgå at kompromittere nogen som helst befalingsmand. Den antog ikke, at dette var sket ved den blotte inddragelse af de pågældende bekendtgørelser. 
Med denne generalkommandoens redegørelse skal her omtalen af hilsepåbudet sluttes. Som det var nævnt i Moltkes skrivelse af 23. maj, havde krigsministeren beordret du Plat afløst. Dette var sket ved en ordre samme dag, hvorved han ansattes som kommandør for 3. linjeinfanteribataillon, medens major v. Vett blev kommandør for 2. forstærkningsbataillon ${ }^{1}$. Du Plat blev senere pladskommandant i Altona. Han faldt i stormen på Dybbøl.

1 Krigsmin. Direkt. f. arm. pers. Kopibog 185 r. Nr. $3^{626 .}{ }^{28} / 5$. 